\title{
The Role of Race in Mortgage Lending: Revisiting the Boston Fed Study*
}

\author{
by \\ Raphael W. Bostic \\ Division of Research and Statistics \\ Federal Reserve Board of Governors \\ Washington, DC 20551
}

Working Paper

December, 1996

First version: December, 1995

JEL Classification: G21, G14, J15, J71

Keywords: discrimination, mortgages, race, credit risk

This paper reexamines claims that non-economic discrimination persists in mortgage loan origination decisions. I find that racial differences in outcomes do exist, as minorities fare worse regarding debt-to-income requirements but better for loan-to-value requirements. Overall, significant racial differentials exist only for "marginal" applicants and are not present for those with higher incomes or those with no credit problems. Thus, the claim that non-economic discrimination is a general phenomenon is refuted. Further, I can say little regarding the existence of discrimination among "marginal" applicants. To conclude that such discrimination exists, one must prove that the observed differences are not due to economic factors.

*This paper is a revised version of one chapter of the author's dissertation. The views presented are solely those of the author and do not necessarily represent the views of the Federal Reserve Board or its staff. This paper was completed as part of my doctoral dissertation. I thank Robert Avery, Don Brown, Glenn Canner, Brian Cromwell, Joel Luebkeman, Roger Nell, John Quigley, John Shoven, Joanne Spetz, Richard Stanton, Scott Stern and seminar participants at the Federal Reserve System Board of Governors and Stanford University for important insights. I also wish to thank the Center for Economic Policy Research, the National Science Foundation, and the Lynde and Harry Bradley Foundation for financial support. 
Strident accusations of rampant racial discrimination in mortgage lending, widespread during the early 1970 's, ${ }^{1}$ have continued to the present. Such complaints have centered on two alleged practices: (i) "redlining," the refusal to lend to particular neighborhoods based on non-economic factors associated with the location of the property, and (ii) individual discrimination, the refusal to lend to individuals due to non-economic characteristics they possess. Although evidence demonstrating the existence of these practices has been limited, ${ }^{2}$ a recent study by the Federal Reserve Bank of Boston concluded that race played a significant role, apart from other economic considerations, in lender decisions on mortgage loan applications in Boston in 1990. ${ }^{3}$ Munnell, et al. (1992) argue that these racial differences in outcomes indicate that individual discrimination was present in mortgage lending in Boston. However, the lack of a precise characterization of the role of race in the lending decision makes it difficult to justify this conclusion. Race could be correlated with important decision variables that are omitted from the analysis in Munnell, et al. (1996). Alternatively, the influence of included variables might vary significantly by race for economically justifiable reasons. In either case, one would observe a significant racial difference in decisions without there necessarily being racial individual discrimination. Only by identifying the exact mechanisms through which race impacts lender decisions can one determine if lenders are acting with racial, as well as economic, motives.

Building on Munnell, et al. (1996), this paper attempts to better interpret these results by describing how race may influence lender decisions to accept or reject loan applications and then exploring further the implications of any observed patterns of racial difference. Starting from the Munnell, et al. (1996) specification, I examine whether the influence of economic decision variables vanes with the race of the applicant and find that this is indeed the case for two key economic decision variables - the debt-to-income ratio and the loan-to-value ratio. The racial differences in treatment for these variables work in opposite directions, with white applicants benefiting in the application of debt-to-income ratio requirements and minorities

\footnotetext{
'See Urban-Suburban Investment Study Group (1977), Devine (1975) on Bronx 1960-70, Erie County (1975) on Buffalo 1973-74, Lyons (1975) on Chicago 1968-72, and Center for New Corporate Priorities (1975) on Los Angeles 1974 for examples.

'Research has been unable to address questions of illegal discrimination directly due mainly to data constraints.

'See Munnell, et al. (1996).
} 
benefiting in the application of loan-to-value ratio requirements. Overall, these two effects combine such that minorities are disadvantaged only among "marginal" applicants; among wealthy applicants or applicants with clean credit histories, no significant differences in outcomes based on race are observed.

These results highlight the inappropriateness of attributing the observed racial differences in outcomes exclusively to individual discrimination, as the pattern of possible bias can be explained in several ways other than discrimination. Differences in outcomes related to the race of applicants may be justifiable on economic bases if significant racial differences in default or prepayment risk due to income shocks, house price movements, or other factors exist. Also, this pattern of racial outcomes inconsistent with a model where antidiscriminatory policy alters lender incentives in ways that produce different lending "rules-ofthumb" across races. These alternate possibilities are explored in future research.

\section{BACKGROUND}

In this section, I discuss the two features that provide a backdrop for my analysis. First, I present a model of the lender decision making process which provides the general framework for analyzing the problem of discrimination in mortgage lending. Next, I describe and discuss Munnell, et al. (1996), the results of which provide the starting point for my empirical approach.

\subsection{The Lender Decision}

It is standard in the literature to assume that lenders, in making decisions, attempt to maximize the expected return to loans. As a result, they consider those factors that affect the profits associated with providing loans. Loan profitability is initially determined by the terms of the loan, which establish the stream of income lenders expect to receive over the life of the loan. Given loan terms, which typically do not vary significantly by race, the level of profits from loans is dependent primarily on two factors, default and prepayment, both of which shorten the life of the loan and decrease the level of profits. Default occurs when mortgagors fail to make payments to service their loans. Default results in lower, and often negative, returns for lenders because the full amount of the loan is not repaid, interest is not 
received, and substantial legal and processing fees are usually incurred to foreclose and resell the property. By contrast, lenders are fully repaid the loan amount in the event of prepayment, so decreased returns occur only when the interest rate at the time of prepayment is lower than its level at origination. Otherwise, lenders can reinvest the prepaid principal and receive comparable returns. Losses via prepayment can arise from refinancing as well as from selling homes prior to the end of the loan term. Thus, the probability that profits will be lower than expected is positively related to the likelihood of default and generally positively related to the likelihood of prepayment,

$$
\mathrm{P}\left(\pi_{\mathrm{i}}<\mathrm{E}(\pi)\right)=\mathrm{f}(\mathrm{P}(\text { Default }), \mathrm{P}(\text { Prepayment })),
$$

and correspondingly the probability that a loan application will be rejected is a positive function of these factors,

$$
P(\text { reject })=f(P(\text { Default }), P(\text { Prepayment })) \text {. }
$$

In modeling lender decisions on making loans, it is assumed that lenders try to minimize the likelihood of default or prepayment upon interest rate declines and thus consider their determinants when examining loan applications. Although the factors which trigger default and prepayment behavior have not been studied extensively, a number of factors are thought to be important. The factors influencing default and prepayment can fall into several broad categories. A number of factors, including obligation ratios, ${ }^{4}$ indicate how well applicants are currently handling debt obligations and provide insight into a prospective borrower's ability to carry the current loan as well as additional future loans over the long run. A second category measures how applicants have handled debt obligations in the past and hence their likely ability to meet monthly payments required to fully amortize the proposed mortgage. Such variables include credit history and income stability. The likelihood of losses due to rational termination, where a borrower defaults, refinances, or sells the house because the house value has declined such that it is less valuable than the outstanding debt, is measured through the presence of personal mortgage insurance (PMI), loan-to-value ratios, and the expected stability of value of the house. Also, certain personal characteristics might signal an applicant's likelihood to default or prepay. A married person, for example, might view the

\footnotetext{
${ }^{4}$ These include debt-to-income and housing-expense-to-income ratios.
} 
house in terms of a family and attach value to it beyond its pure financial value. This might decrease the likelihood to default rationally but increase the probability of prepayment, because changes in family composition might make other homes more attractive in the future. Finally, the terms of the loan - interest rate and term duration - will determine the rate of return of the loan for lenders. We can summarize this as

$$
P(\text { Default })=f(A, H, R T, P, T) \text { and } P(\text { Prepayment })=f(A, H, R T, P, T),
$$

and therefore rewrite (2) as

$$
P(\text { reject })=f(A, H, R T, P, T)
$$

where A represents factors demonstrating the ability to carry the loan, $\mathrm{H}$ is a vector of historical default and prepayment factors, RT symbolizes factors affecting the likelihood of rational termination, $\mathrm{P}$ stands for personal characteristics impacting default and prepayment likelihood, and $\mathrm{T}$ represents loan terms. This is the basic model used in most of the current literature and the one my analysis builds upon.

Given this theoretical context, significant differences may exist in rejection rates by race in the absence of prejudicial discrimination. Lenders might be using race as a proxy for the determinants in (4). Systematic racial differences may exist in A, H, RT, P, or T, or in factors that impact A, H, RT, P, or T over time, in which case significant differences in rejection rates would merely be reflecting this. Only if such differences are not found can we assert that non-economic discrimination in the form of prejudice exists. The question of nature of discrimination in mortgage lending thus reduces to establishing whether lenders are using race as a signal or proxy for the factors in (4) or are simply acting in a prejudicial manner. While prejudicial discrimination is clearly illegal, it should be noted that the use of race as a proxy for other factors, called statistical discrimination, is also an illegal practice.

\subsection{Previous research and Munnell, et al.}

Much of the early research on discrimination in mortgage lending focused on redlining, primarily due to limitations on available data. ${ }^{5}$ Although general redlining was not

\footnotetext{
${ }^{5} \mathrm{~A}$ number of these studies are summarized in Benston, Horsky, and Weingartner (1978) and Canner (1982). Many other studies of discrimination are included in Hearings before the Committee on Banking, Housing, and Urban Affairs, United States Senate (1975).
} 
consistently demonstrated, this research did seem to indicate that "some discrimination by individual institutions may exist. In this regard some research does support the claim that minority applicants have a greater probability of being denied a loan than white applicants with similar characteristics." (Canner (1982), p.10) As a result, much attention shifted from concerns about redlining to discrimination at the individual level, with researchers trying to determine whether race was being used as a signal or a prejudicial variable by lenders. This research has become more sophisticated as more data have become available. Due to data constraints, early research centered on comparing rejections and acceptances of applications by race on both individual and geographic average bases. Typically only two explanatory variables, income and race, were used to represent the relevant lender decision factors in this work. Many studies, including the Pulitzer Prize winning "Color of Money" series on the Atlanta mortgage market, have been conducted using this model. ${ }^{6}$ These studies all used the same basic analytical approach. Using data on the distribution of originated loans or on the outcomes of loan applications, the studies compared outcome (acceptance or rejection) frequencies among neighborhoods or individuals with similar characteristics but different racial backgrounds. ${ }^{7}$ Across the board, evidence consistent with possible bias against minorities, as measured by comparatively fewer loans made to minority neighborhoods or higher rejection rates for minority applicants, was found.

This model for detecting discrimination is inadequate. Rather than estimating equation (4) above, these studies use only one measure of the borrower's ability to carry the loan, income, to characterize the important factors for lender decisions. Therefore, finding racial differences under a model where only income and race are used as explanatory variables does not imply individual discrimination because it could be that race was being used as a signal for one of the important omitted variables from equation (4). If so, observed significant racial differences could merely be representing differences by race across these omitted variables

\footnotetext{
${ }^{6}$ See Dedman (1988) and Canner and Smith (1992), among others.

7"The Color of Money," for example, compared predominantly white and predominantly black neighborhoods which had very similar median income levels. Canner and Smith (1992), using 1990 data mandated by the Home Mortgage Disclosure Act, compared applicants in broad income and neighborhood composition classes. Neighborhood composition refers to the minority percentage of the population in the neighborhood where the target house is located.
} 
rather than the isolated impact of race on lender decisions. ${ }^{8}$

In response to this inability to address conclusively the question of individual discrimination, the Federal Reserve Bank of Boston developed a data set based on a survey of lenders that expanded upon data mandated by the Home Mortgage Disclosure Act to include economic factors identified in (4) but omitted in previous research. Munnell, et al. used these data to conduct the most comprehensive analysis to date on the topic. ${ }^{9}$ To explore discrimination, Munnell, et al. include a race dummy, $\mathrm{R}$, in (4) to reflect the impact that racial status may have on credit decisions. They argue that, in the absence of discrimination, $\mathrm{R}$ should be insignificant in a statistical estimation. ${ }^{10}$ However, if discrimination exists, then $\mathrm{R}$ will be positive and significant. The results of this analysis found the same patterns of possible bias as earlier research, as the coefficient on race was significant and positive. From this, Munnell, et al. concluded that the significant positive race dummy means that minorities face adverse individual discrimination in lending.

The results of the Munnell, et al. study have been criticized on several grounds. First, upon examination of the raw data, many errors were evident, so, arguably, Munnell's results might be driven by these errors. However, several studies that corrected these problems found that racial differentials, and by extension discrimination, remain. " A second line of criticisms stemmed from the fact that average default rates on loans were found to be equal across racial groups. ${ }^{12}$ This, however, is not by itself sufficient to demonstrate the absence or presence of illegal discrimination. ${ }^{13}$ Additional concerns surround the specifications used in

\footnotetext{
'To be fair, this was recognized by the early researchers. Data constraint drove their approach. In a slight advancement, Gabriel and Rosenthal (1991) attempted to account for these previously omitted factors by using a broadly defined measure of default risk. However, even this study inadequately dealt with the entire range of decision variables lenders use to determine whether and under what terms a loan application is likely to be profitable.

${ }^{9}$ The use of individual application data rather than total number of loans allows Munnell, et al.(1996) ${ }^{60}$ sidestep marketwide issues, such as varying levels of demand across locations, that had weakened the results of earlier studies.

${ }^{10} \mathrm{R}=1$ if the applicant was a minority. This approach focuses on racial discrimination. However, if other types of discrimination are present, then other borrower attributes, such as gender or marital status, would need to be included. In their study, Munnell, et al. (1996) include these variables as controls. They were found to be insignificant.

"See Liebowitz (1993) and Carr and Megbolugbe (1993).

${ }^{12}$ See Becker (1993), Brimelow (1993), and Brimelow and Spencer (1993).

${ }^{13}$ The focus on average default rates does not have clear implications for the existence of discrimination, which occurs on a personal level. Comparing population averages compares the broad treatment of groups rather than the treatment of specific individuals across groups, which is the focus of anti-discriminatory legislation. In actuality, discrimination can be present with equal average default rates across groups or it can be absent when groups have different average default rates. See Galster (1993).
} 
the analysis. Some have argued that important explanatory factors for predicting default were not included in the analysis (although available in the data) and that these omissions drive the results. ${ }^{14}$ These arguments were later refuted. ${ }^{15}$ A further specification argument is that the true relation between the rejection/acceptance decision and the explanatory variables is not the simple linear relation implied by previous regression analyses, so that using a linear specification does not introduce explanatory variables in ways that lenders make use of them in actuality.

\section{METHODOLOGY}

Although Munnell, et al.'s finding of racial differentials has been robust to previous critiques, claims of discrimination are premature. As noted earlier, it may be that some lender decision variables have been omitted. Perhaps all important factors in (4) are not present in their specification. Also, it may be the case that lenders use different "rules-ofthumb" that vary by race. These different decision algorithms may be justified on an economic basis and therefore may not indicate individual discrimination. Also, outside forces, such as social or political factors, may have acted to change the considerations lenders m\&e in arriving at decisions. In this case, (4) would not be the proper specification. Answers to these questions can only be obtained by further understanding the nature of the role of race in mortgage lending decisions.

In conducting this further exploration, I begin by hypothesizing that, in considering minority applications, lenders use different criteria for making decisions. In particular, I posit that lenders still consider the economic variables summarized in (4), but that they use different weights on these variables for minority applicants. Why might I expect this? First, the minority population has a substantially different demographic profile than the white

\footnotetext{
${ }^{14}$ This argument was levied most strongly by Zandi (1993), who demonstrated that the inclusion of two variables in particular - whether the application met institutional guidelines and whether there was unverifiable information in the application - significantly reduced the observed amount of the racial difference. Zandi estimated that the reduction was on the order of $50 \%$.

${ }^{15}$ Carr and Megbolugbe (1993) reexamined Zandi (1993) and, while finding that these variables indeed reduced the magnitude of the racial difference, argued that the newly included variables were themselves tainted with a racial element independent of more objective considerations. Because of this, Carr and Megbolugbe conclude "the basic result of the Boston Fed study seems immutable: Boston-area lenders appeared to have statistically discriminated against minority applicants in 1990." (Carr and Megbolugbe (1993), p. 311)
} 
population. Minorities are less well-endowed financially and minority neighborhoods generally have lower valued properties than corresponding white neighborhoods. This, along with other differences, could mean that signals typically used by lenders as indicators of default and prepayment likelihood represent different likelihoods across races. Also, the strong social sensitivity to race might induce lenders to view race as a salient factor to consider in making decisions. ${ }^{16}$

Empirically, this hypothesis is operationalized by interacting race with the economic variables included in (4). The estimated equation becomes

(5) $\quad P($ reject $)=f(D, R, D * R)$

where D represents A, H, RT, T, and P from (4) and R is race. Assuming a probit estimation, the entire specification becomes:

$$
\mathrm{E}[\mathrm{P}(\text { reject })]=\Phi\left(\sum \beta_{\mathrm{Di}} \mathrm{D}_{\mathrm{i}}+\beta_{\mathrm{R}} \mathrm{R}+\sum \beta_{\mathrm{Gi}} \mathrm{D}_{\mathrm{i}} \mathrm{R}\right)
$$

where $D_{i}$ is the coefficient for the ith factor of $D, G_{i}$ is the coefficient for the ith factor of the interactive term, $\beta_{\mathrm{R}}$ is the race coefficient, and $\Phi(\bullet)$ is the standard normal cumulative distribution function.

This new specification permits estimation of racial differences in the marginal effects of the economic regressors, and so a test of the hypothesis that the criteria for evaluating loan applications differ by race. If such differences are found, this would be consistent with the hypothesis that lenders use race as a behavioral signal. Further, these differences will provide important clues as to the nature of such signals. Given that individual characteristics have specific relevance for lenders, differences in the weighting of these characteristics will focus attention on specific behavioral considerations. Observed differences will therefore highlight the areas where lenders believe significant behavioral differences may exist among racial groups.

Given my hypothesis that lenders make selective decision rule changes for minority applicants, I expect that the marginal effect of economic variables will remain unchanged from previous estimates for white applicants and shift for minority applicants. Ex ante, it is difficult to predict how lenders might adjust "rules-of-thumb," and thus predictions about

\footnotetext{
${ }^{16}$ This was evident in talking to individual lenders, who emphasized increased institutional sensitivity to racial issues.
} 
shifts in the influences of individual economic variables across races are hard to make. In addition, this model implies that lenders do not apply non-economic discrimination, and therefore I expect the coefficient on the race dummy variable, which reflects this type of discrimination, to be insignificant.

The model in (6) also permits a test of the hypothesis that the effect of race on loan application evaluations differs according to the economic characteristics of the applicant. This will permit an exploration of variations in racial differences over various income and broad demographic characteristics and provide further insights into the general nature of the role of race in mortgage lending decisions.

\section{RESULTS AND ANALYSIS}

\subsection{Data. Sample Statistics, and Initial Results}

In estimating equation (6), I use a subset of the publicly available expanded data set compiled by the Federal Reserve Bank of Boston and used in Munnell, et al. (1996). ${ }^{17}$ In addition to the information required by the Home Mortgage Disclosure Act of 1975 (HMDA), this data set includes information on an expanded set of applicant and property characteristics, including credit histories and employment measures. Since, as was noted above, errors are known to exist in the data, all analyses use a "clean" data set as prescribed by Carr and - Megbolugbe (1993). ${ }^{18}$

The variables used in the analysis are listed in Table 1. As they are standard in the literature, I will only discuss them briefly here. The dependent variable, DENIED, is a dummy variable that indicates whether an application was accepted or rejected. The next sets of variables measure the applicant's ability to support the loan, the probability that an applicant will default, and other characteristics of the applicant, property, or loan package that are thought to have implications for the likelihood of default and prepayment. For an

\footnotetext{
${ }^{17}$ This set was altered by the Federal Reserve Bank to preserve the anonymity of individual applicants.

${ }^{18}$ The clean data set omits all observations that fail criterion 1, 2,3, or 4 as specified in Carr and Megbolugbe (1993). These criteria are (1) loan-to-value ratio $>3$, (2) effective annual interest rate $>.20$, (3) effective annual interest rate $<.03$, and (4) housing expense-to-income ratio $>$ total expense-to-income ratio. The analysis was also conducted using the entire sample and, as with the other studies, the presence of outliers and errors does alter the results. See Table Al in the Appendix.
} 
extended discussion of the rationale behind the inclusion of each of these variables, see Munnell, et al. (1996).

Table 2 lists the means and medians of selected variables from the sample by race and application disposition. These figures conform to much of the existing literature and provide support for my hypothesis that the minority and white populations differ demographically. The usual racial difference in the outcome of the accept/reject decision before accounting for differences uneconomic conditions is once again observed. Minorities have a 27.8 percent rejection rate while white applicants are only rejected 10 . O percent of the time. Minorities have substantially less income and wealth than whites in the sample. They have only about half of the levels of liquid assets and net wealth found in the white population. Also, with 30 percent more assets and net wealth, accepted applicants are consistently better endowed than denied applicants for both ethnic groups. This pattern - white and accepted applicants better positioned than minority and denied applicants - holds for all the financial variables. Higher relative debt and housing expense levels, as well as lower downpayments, are observed for minority and denied applicants. Similarly, white and accepted applicants generally have better credit histories and public records than minority and denied applicants. However, in a departure from the general trend, minorities have better mortgage histories than whites. Finally, on the social variables, such as percentage of applicants with dependents and percentage of applicants who are married, differences across races are also seen.

Since economic variables are thought to be correlated with minority status, multicollinearity is an issue for evaluating the validity of estimated coefficients. Table 3 presents a correlation matrix of the variables used in the estimation. As expected, minority status is significantly correlated with all the included economic variables. However, in only 3 cases (plus the independent variable) is the correlation larger than .15 and in no cases is the correlation above .25 . Such small correlations suggest that multicollinearity will not be a major problem in the estimation.

Table 4 compares probit estimates using the specification based on (4) versus the new interactive specification. The first specification includes the variables used in Munnell, et al. (1996), which broadly captures those variables affecting an applicant's probability of default. 
The results of this estimation are in line with previous results. ${ }^{19}$ A strong racial effect is found, as MINORITY is positive and significant. In addition, the coefficients on the other significant variables conform with what is found in the literature.

In comparing this with the interactive specification, a likelihood ratio test indicates that the new specification explains significantly more of the variance than the standard approach. Moreover, as is evident, the inclusion of interaction terms produces a very different picture of the role of race in mortgage lending decisions. MINORITY, the noninteracted racial dummy, loses significance, and in its place, two interactive terms, BLDEBT and BLLTV, are significant with opposite signs. This would seem to suggest that race, by itself, is not a significant factor in the decision to originate a loan. However, race appears as a factor when considered in conjunction with other economic decision factors. By contrast, the results for the other individual characteristics remain largely unchanged by including the interactive terms. No new variables become significant and, as expected, the previously significant variables all are still significant in the new specification. Further, the magnitudes of the significant coefficients are not substantially different in the two cases. ${ }^{20}$

These results are consistent with the hypothesis that lenders apply different criteria for evaluating applications from different racial groups. The stable, significant coefficients on personal financial characteristics across all specifications imply that lenders make decisions based on economic considerations. However, that race is a significant cofactor on some economic dimensions suggests that lenders also appear sensitive to the race of the applicant in assessing some of these economic factors. The specific results suggest that loan evaluations for minorities have been adjusted to increase approvals with a minimal effect on default risk. Essentially, the results indicate that, in dealing with minorities, lenders focus more on the ability of applicants to service their overall debt load (the positive coefficient on BLDEBT)

\footnotetext{
${ }^{19}$ Although this literature typically uses logits, I use probits for much of my analysis. The narrower tails in the standard normal distribution fit the data slightly better than the tails in the logistic distribution. In general, using either approach produces similar results.

${ }^{20}$ This same exercise was conducted using a number of different specifications. An estimate using a more parsimonious set of regressors produces the same pattern (see Table A2 in the Appendix). Also, because participation in special programs differs greatly by race, an estimate including a dummy variable for such participation was run. Again, the results mirrored the general findings (see Table A3 in the Appendix). Since these specifications are not significantly different from one using all the interactive terms and produce a similar level of explanatory power ( $\mathrm{R}{ }^{2}$ near .338 ), the subsequent discussion focuses on the original specification.
} 
and less on the incentive the borrower has to "walk away" from the loan if housing values decline (the negative coefficient on BLLTV). ${ }^{21}$

\subsection{Rejection Probabilities and the Net Effect of Race}

The magnitude of these two effects on lending decisions can readily be calculated from the regressions, but such an approach lacks intuitive appeal. To characterize these differential racial influences, two tests are conducted. First, the racial differences in the marginal effects of the debt-to-income and loan-to-value ratios are estimated. Next, I construct profiles of rejection probabilities over ranges of debt-to-income and loan-to-value for different populations. For both of these, hypothetical applicants are created to see if marginal effects differ with creditworthiness. In these ways, is is possible to obtain a clearer understanding of the nature of the observed racial differences and how lenders' decision rules may vary across races.

Calculating Rejection Probabilities. From (6), it is clear that estimated rejection probabilities will vary with the characteristics of the applicant. I can therefore observe how marginal effects shift with these characteristics. To do this, I calculate expected rejection probabilities at sample means for four groups: the overall sample, the minority sample, a high income subsample, and a low income subsample. ${ }^{22}$ This allows for a determination of whether income level affects the magnitude of racial differences and differences in the marginal impacts of the economic variables across races.

Sample statistics of these populations are shown in Table 5. The general patterns conform to expectations. Rejection rates in the minority and low income samples are significantly higher than in the full sample and the high income subsample. Also, minorities and those with lower incomes have similar financial characteristics. Not surprisingly, the high income population has lower obligation ratios and purchases more expensive houses than the minority and low income populations. Also, those with higher incomes generally have better credit histories, although their mortgage histories are a bit worse. Perhaps the most interesting

\footnotetext{
${ }^{21}$ This "walking away" was described a rational termination earlier.

${ }^{22}$ The high income and low income populations are defined as greater than and less than the 75th and 25th percentile income levels of the sample, respectively.
} 
figure is that the low income population has the lowest average loan-to-value ratio.

Because a number of the variables in (6) are dummy variables, rejection probabilities calculated at sample means for all regressors will not be valid. To adjust for this, I construct four hypothetical "applicants," who vary in the "cleanliness" of their credit records, to use in calculating these probabilities for my two tests. The types are: ${ }^{23}$

-Person A good credit history

-Person B good history except bad mortgage record

-Person C good history except bad consumer credit record

-Person D all histories are bad

Table 6 indicates the frequency of these types in the data and their observed rejection rates. Type A applicants are rarely rejected, while type D applicants are rejected quite frequently. Interestingly, types $\mathrm{B}$ and $\mathrm{C}$ have similar rejection rates.

Individual Marginal Effects. To determine the role of race in the marginal effects of the debt-to-income and loan-to-value ratios, expected probabilities of loan rejection are computed explicitly using equation (6). Using sample means and hypothetical applicant types, I first calculate expected rejection probabilities of applicants as if they were white or minority. I then recalculate expected probabilities of rejection treating the applicant as if they were of a different race on the interactive variable of interest only. Procedurally, this results in expected probability calculations that differ across races by only a single term, the coefficient of the interaction variable of interest. In other words, this approach provides estimates of marginal effects ceterus paribus.

Results are shown in Table 7 for debt-to-income and loan-to-value using Type B applicants at the various sample means. These relations are representative of similar calculations for the other hypothetical applicants. As expected, rejection probabilities have a negative relation with income level, as high income individuals have the lowest and lower income applicants the highest expected rejection rates among income classes in all cases. Rejection rates at the minority means generally fall between those at the low income and the overall sample means. This suggests that the average minority applicant has better economic

\footnotetext{
${ }^{23}$ All applicants are buying single family homes, have an outside employer (i.e. are not self-employed), and have PMI insurance.

${ }^{24}$ Notwithstanding the very small sample size, this is what one would expect.
} 
characteristics than lower income applicants but is not objectively comparable to the average applicant in the general population.

Regarding expected rejection rates, minorities fare worse regarding the debt-to-income ratio. In both specifications, minorities are rejected significantly more than white applicants with equivalent debt-to-income ratios after holding all else constant. These marginal rates exceed 300 percent and in some cases approach 400 percent. Further, racial differences increase as applicants' income level decreases, although the general levels of difference are so large that these within-group movements might seem insignificant. Lower income minority applicants are rejected almost four times more often, while higher income minority applicants face a rejection rate 3.44 times higher than equivalent white applicants on this dimension. The magnitude of outcome differences is similar when white applicants are treated as minorities on the debt-to-income ratio dimension (rejection rates 3 to 3.5 times higher).

By contrast, for loan-to-value ratio considerations, minorities have strikingly lower expected rejection rates. These rate differences are of very similar magnitudes to those found for debt-to-income. However, unlike debt-to-income, differences in magnitudes do not consistently vary systematically with income level.

Probability of Reiection Profiles. In addition to examining the marginal effects of the two variables at their mean values for hypothetical applicants from various populations, I explore how these marginal effects shift over ranges of debt-to-income and loan-to-value ratios. To do this, I calculate expected probabilities of rejection over ranges of the two variables. From these I graph expected rejection rate profiles for the hypothetical applicants at the four sample means. As with the marginal effect analysis, I compute four probabilities at each sample for each hypothetical applicant. Examples of these profiles are shown in panels (i) through (iii) of Figure 1. As the profiles for the hypothetical applicants are all very similar and vary only by magnitude of the rejection probability, only the profiles for applicant B are shown. ${ }^{25}$

These profiles demonstrate the same general patterns regarding the effect of white treatment of minority applicants and minority treatment of white applicants that were

\footnotetext{
${ }^{25}$ The marginal effects are slightly smaller for hypothetical applicant D than for applicants B and C, while those of applicant A are slightly higher. However, the general relations hold.
} 
observed in examining marginal effects. For debt-to-income ratios, minority treatment increases the probability of rejection and white treatment decreases the rejection probability at all debt-to-income ratio values. Analogous to the debt-to-income ratio, rejection probability movements for loan-to-value ratios conform with those observed when comparing marginal effects. An applicant's probability of rejection increases with white treatment and decreases with minority treatment.

Further, the magnitude of marginal effect of race varies with the value of the variables. As the level of debt-to-income decreases (i.e. as the debt burden decreases), the marginal effect decreases. For example, at low income subsample means, moving from a debt-toincome level of .37 to one of .27 nearly halves the racial effect (from 14 or 15 percent to 7 percent, see Figure 1, Panel (ii)). Moreover, as applicants become "safer" credit risks, differences across races on this dimension decrease. For loan-to-value ratios, the minority applicant probability of rejection is relatively constant over the entire range of loan-to-value ratios considered while that of white applicants falls with loan-to-value. So, like the debt-toincome ratio, an increasing marginal effect is observed as the applicant's riskiness increases.

Net effect of race. In addition to the marginal effects of the individual variables, I can determine the net effect of race by combining these effects and observing expected rejection probabilities across individuals and sample means. I do this in two ways. First, I compare rejection probabilities of white and minority applicants with the characteristics of hypothetical applicants A through D at the various sample means. Second, I look at the overall profiles to see if racial differentials shift with debt-to-income and loan-to-value levels.

Results of the first exercise are shown in Table 8. Two categories of applicants, those with good credit histories and those with higher incomes, show no significant racial differences. In none of the seven cases where the applicant was either in the high income group or without credit problems is the difference in expected rejection rates statistically different from zero. A significant racial effect is observed for all other cases, which represent "marginal applicants." Generally, for non-wealthy minority applicants, problems with credit result in larger negative impacts than observed for non-wealthy white applicants. Such divergences exist regardless of the type of credit problem, as they are observed for applicants with either mortgage or general credit problems. Further, these gaps increase as the level of 
wealth decreases, so lower income applicants with credit problems face larger differences than similar applicants with higher income.

Table 9 translates these results to relative rates of rejection. The largest differentials are observed for applicants with poor mortgage records (see Applicant B in the table). Among those with poor mortgage histories, minority applicants have a rejection rate almost three times higher than white applicants. These differences are somewhat reduced among applicants with poor consumer credit histories only (Applicant C). This reduction is caused by increases in expected rejections of white applicants. Finally, for applicants with generally poor credit (Applicant D) the racial gap in percentage terms is even less than in the other two cases. This suggests that racial differences decrease as applicants become less "marginal" in either direction; that is, applicants who are easily accepted or rejected appear to receive very similar treatment, regardless of race.

These patterns are further seen when overall profiles are explored. Panel (i) of Figure 2 shows the profile of hypothetical applicant B over ranges of debt-to-income and loan-to-value at the general population sample means. ${ }^{26}$ The shaded ranges in the figure show the areas where racial differences in expected rejection rates are significant. In the debt-to-income case, of the 905 applicants in the sample with these characteristics, approximately 5570 are included in the shaded region. Of relevant minorities, nearly two-thirds are included. ${ }^{27}$ At the low income and minority sample means, the magnitude of racial differential on affected applicants becomes even larger. For example, at low income subsample means, race is a significant factor for debt-to-income requirements for nearly 6770 and 7590 of all and minority applicants, respectively. Thus, racial disparities on this dimension are relevant for a significant portion of the population. For loan-to-value, observed racial differences are relevant for fewer applicants, but are still a factor for a significant percentage of the population (approximately $33 \%$ and $20 \%$ of all and minority applicants, respectively). Interestingly, the racial gap increases as loan-to-value ratios decrease. This implies that racial differences increase as the risk of rational default decreases, which is quite surprising. One

\footnotetext{
${ }^{26}$ Again, these profiles are indicative of those seen for hypothetical applicants C and D.

${ }^{27}$ These estimates were obtained by using applicants in the sample with any credit problems whatsoever as the reference group,
} 
might have expected that as applicants become "safer," in terms of decreased likelihood of rational default, they would be viewed in a more similar fashion.

These patterns can be contrasted with those for hypothetical applicant A, whose profiles at overall sample means are shown in panel (ii) of Figure 2, and for a high income hypothetical applicant, whose profiles are in panel (iii) of Figure 2. In both cases, although the gaps shift in a similar way to that seen above, at no points are the differences in rejection probabilities statistically significant. Racial differentials do not exist for any members of these populations.

\section{DISCUSSION}

Although significant, the observed racial patterns cannot be taken as definitive evidence of discriminatory treatment in mortgage lending, as they could be justified under several economic scenarios:

(i) racial differences in the propensity to default or prepay due to declines in house values (LTV effect);

(ii) racial differences in the propensity to default or prepay due to income shocks (debt burden effect); and

(iii) a nonlinearity in the relationship between termination risk and these two variables. $^{28}$

Using this rationale, lender variation of loan-to-value ratio requirements would suggest that white applicants are more likely to terminate loans through default or prepayment due to declines in house values than minority applicants. If true, this would explain the positive shift that minority applicants receive from lenders. Interestingly, the flat profile for minority applicants in all cases suggests that lenders view minority applicants as equally likely to terminate loans rationally independent of the level of personal investment. Similarly, the observed debt-to-income differential would reflect an increased likelihood that minority applicants default due to inabilities to cover loan repayments or prepay due to income windfalls. To consider the default case, such defaults might be caused by severe negative income shocks that force applicants to choose how to allocate limited funds among debts and

\footnotetext{
${ }^{28}$ Analysis using a logit specification produces substantively equivalent results. (see Table A4 of Appendix) Thus, although nonlinearities are potentially important, I abstract away from this possibility for the remainder of this discussion.
} 
required daily expenses. Given that minority applicants typically have less available wealth, it is plausible that these applicants are more susceptible to facing such difficult allocation decisions. This story is also consistent with the observed reduction in the racial gap as debtto-income levels decreased. The less burdened an applicant is, the more likely that applicant will be able to withstand such shocks and repay all debts. If either or both of these conditions holds, then lender behavior would be justified on economic efficiency grounds and one would expect to observe differences by race. Corresponding arguments can be made for prepayment.

Only if such economic mechanisms fail to explain either of these racial interaction effects can we conclude that the results reflect prejudicial racial discrimination. As these possibilities have not been explored, conclusions of individual discrimination from evidence of racial differences in treatment cannot reasonably be made. In future work, I will explore the proposition that lender biases are economically motivated to further evaluate the question of racial discrimination.

Another possible explanation for observed differences is that policy and other social factors may have altered the lending market. Legislation such as the HMDA and the Community Reinvestment Act (CRA) may have fundamentally changed the market by introducing a new element with possible profit implications, race. ${ }^{29}$ In particular, such legislation established incentives to provide more loans to minority applicants, even though the characteristics of these applicants were unchanged. Failure to respond to this legislation in some fashion could affect profits, either through decreased business volume or reduced investment opportunities. ${ }^{30}$ This new environment could force lenders to rethink their approaches to providing lending services. Rather than focusing solely on the factors identified in (4), lenders might now consider origination decisions in light of future impacts on general fair lending perceptions and institutional CRA performance.

\footnotetext{
29 The HMDA requires lending institutions to disclose statistics reflecting their records in providing housing credit to their service areas. This Act was based on the assumption that institutions found not to be meeting these obligations would face adverse reactions from citizens and public officials. Passed in 1977, the CRA was in part intended to assure fair access to credit for minorities and low income people. Via its provisions, a structure is established by which institutions can be penalized by Federal regulatory agencies if their lending activity departs from industry norms.

${ }^{30}$ Instances of such penalties are described in Dennis (1980) and Macey (1994).
} 
A third and intermediate answer for why might we observe such a pattern of racial differences, even in the absence of racial discrimination, might lie in the roles of the two interactive variables, loan-to-value ratio and debt-to-income ratio, in the lending decision and the presence of Federal legislation. The loan-to-value ratio is not a direct measure of the capacity of an applicant to pay. Rather, it is used as a hedge against an applicant simply walking away from an obligation by requiring a significant borrower stake in the transaction. Minority applicants may have less available capital and therefore systematically require higher loan-to-value ratios than comparable white applicants. If so, the same loan-to-value ratio represents a different level of commitment of total household wealth to the purchased home, and so, conceivably, a different willingness to default or prepay. If true, giving loan-to-value ratios the same weight across all applicants would effectively penalize minorities for having less initial wealth rather than for having a lower capacity and willingness to pay off the loan (i.e., a higher default probability). Increased sensitivity to race, through civil rights awareness and the introduction of laws such as the CRA and the HMDA, may have induced lenders to recognize this difference and become less stringent on this dimension in considering loan applications. Still mindful of the incentives to minimize losses due to default and aware of easing the loan-to-value safety net for minorities, lenders also may have become more stringent on the debt-to-income ratio requirement, another measure of termination risk, particularly for default, for minorities.

The outcome of this scenario is a stratified market where the net effect of race on the overall origination decision depends on a set of factors, paramount among them being wealth and credit history. Essentially, this story argues that increased sensitivity to race may have created a market where, based on historic realities, races are treated differently on specific economic dimensions, which has an adverse effect primarily for "marginal" applicants.

\section{CONCLUSIONS}

This paper has further explored discrimination in home mortgage lending by using a model based on the notion that lenders use different criteria for assessing applications from members of different racial groups. This model suggests the use of an empirical specification that expands on that employed in earlier studies. The results using this broader approach can 
be summarized as follows:

1. Racial differentials are observed on two dimensions. Minority applicants fare worse regarding assessment on debt-to-income ratio requirements but fare better regarding assessment on loan-to-value ratio requirements.

2. At the margin, the influence of race declines as the ratio of debt-to-income decreases and as the loan-to-value ratio decreases.

3. Taken together, these two racial effects result in an overall negative racial differential, although this is statistically significant only for "marginal" applicants. Statistically significant racial differences were not observed for wealthy applicants or applicants with clean credit histories.

4. Overall, the average minority applicant who does not have a completely clean credit record is rejected significantly more often than a similar applicant who is white. The size of this racial gap decreases as debt-to-value ratios decrease and as loan-to-value ratios increase.

These results are consistent with the proposition that lenders may use different "rules-ofthumb" in considering loan applications across races. The preceding analysis suggests that these differences have a very particular quality. Minorities are not penalized along the loanto-value dimension, as rejection probabilities for minority applicants do not vary over a wide range of loan-to-value ratios. On the other hand, minority applicants face significantly more stringent debt-to-income requirements. Further, the influence of race changes over ranges of these variables. The divergence in outcomes based on race decreases as an applicant's debt burden decreases and as the loan-to-value ratio increases.

The combined effect of these two racial disparities differs with the characteristics of the applicant. Applications by wealthy individuals or by those with "clean" records do not receive differential treatment based on race by lenders. It appears that the two effects offset for these populations. This finding is novel and contrasts with those found in most of the literature, which usually find significant racial differences in outcomes. Only when applicants are "marginal," in the sense of posing significant risks of default, do significant racial gaps emerge. In particular, the negative racial effect for debt-to-income requirements outweighs the loan-to-value effect, resulting in a negative overall effect of race.

These results speak to the ongoing debate about the results of Munnell, et al. (1996). The 
interpretation that racial individual discrimination is unambiguously present in the data is refuted. For certain segments of the population no evidence of bias is evident. The effect found in Munnell, et al. (1996) does, however, conform to the implied experiences of a significant portion of the sample population (i.e., the non-wealthy).

Hunter and Walker (1996), in exploring the significance of education and credit history as signals for lenders, come to a similar conclusion in noting that those with "the best application profiles are treated similarly."(p. 14) The authors conclude that observed racial differences are a result of lenders possessing a more informative posterior probability distribution of repayment for whites than minorities, which leads to differential weighting of relevant decision variables. Like the conclusion of discrimination in Munnell, et al. (1996), though, this information-based conclusion is premature in the absence of evidence regarding underlying economic differences between the white and minority populations.

It is important to emphasize that these observed racial differences in decision outcomes do not necessarily imply that discrimination is currently present in the lending market. As noted, these differences in the implied default and prepayment risk formulas could reflect several economic phenomena. Finally, a more complete and, if possible, mathematical understanding of how lenders consider specific economic variables in making accept/reject decisions is needed. 


\section{BIBLIOGRAPHY}

Becker, G.S. (1993), “The Evidence against Banks Doesn't Prove Bias,” Business Week, 33, April, 13.

Benston, G. J., Horsky, D. and Weingartner, H.M. (1978), "An Empirical Study of Mortgage Redlining," Monograph Series in Finance and Economics Number 5, New York University, Salomon Brothers Center for the Study of Financial Institutions, New York.

Brimelow, P. (1993), "Racism at Work?," National Review, 45, April 12.

Brimelow, P. and Spencer, L. (1993), "The Hidden Clue," Forbes, 48, January 4.

Canner, G.B. (1982), "Redlining: Research and Federal Legislative Response," Board of Governors of the Federal Reserve System, October, Washington.

Canner, G.B. and Smith, D.S. (1992), "Expanded HMDA Data on Residential Lending: One Year Later," Federal Reserve Bulletin, 78(9), pp. 801-824.

Carr, J.H. and Megbolugbe, I.F. (1993), "The Federal Reserve Bank of Boston Study on Mortgage Lending Revisited," Journal of Housing Research, 4(2), pp. 277-313.

Center for New Corporate Priorities (1975), Where the Monev_Is: Mortgage_Lending.Los Angeles County, Peace Press, Los Angeles.

Dedman, B., et.al. (1988), "The Color of Money," series, The Atlanta Journal and the Atlanta Constitution, May 1-4.

Dennis, W. L. (1980), Federal Regulation of Banking.Redlining and Community Reinvestment. Warren, Gorham \& Lament, Boston.

Devine, R.J. (1975), Where Lender Looks First: A Case Studv of Mortgage Disinvestment in Bronx County, 1960-1970, National Urban League, Washington.

Erie County Citizens Organization (1975), Redlining and Disinvestment in Buffalo, The Organization, Erie County, NewYork.

Gabriel, S.A. and Rosenthal, S.S. (1991), "Credit Rationing, Race, and the Mortgage Market," Journal of Urban Economics, 29(3), pp. 371-379.

Galster, G.C. (1993), "The Facts of Lending Discrimination Cannot be Argued Away by Examining Default Rates," Housing Policy Debate, 4(1), pp. 141-146.

Hunter, W.C. and Walker, M.B. (1996), "The Cultural Affinity Hypothesis and Mortgage Lending Decisions," Journal of Real Estate Finance and Economics, 13(1), pp. 57-70. 
Liebowitz, S. (1993), “A Study That Deserves No Credit," The Wall Street Journal, September 1.

Lyons, A. (1975), Conventional Redlining in Chicago: A Case Study, Chicago.

Macey, J.R. (1994), "Banking By Quota," The Wall Street Journal, September 7.

Munnell, A., Browne, L., McEneaney, J., Tootell, G. (1996), "Mortgage Lending in Boston: Interpreting the HMDA Data," American Economic Review, 86(1), pp.25-53.

University of Illinois at Chicago Circle, Urban-Suburban Investment Study Group (1977), Redlining and Disinvestment as a Discriminator-v Practice in Residential Mortgage Loans, Dept. of Housing and Urban Development, Office of Assistant Secretary for Fair Housing and Equal Opportunity, Washington.

Zandi, M. (1993), “Boston Fed's Bias Study Was Deeply Flawed,” American_Banker, August 19. 


\section{Table 1: Variable Definitions}

Dependent Variable

Denied

$=1$ if application was denied

$=\mathrm{O}$ otherwise

\section{Measures of Ability to Support Loan}

Debt-to-Y Ratio

$=$ ratio of monthly payments on existing debt to monthly income

Net Worth $\quad=\quad$ total assets minus total liabilities

Measures of Probability of Default

$\operatorname{Pr}($ Unemp.)

= 1989 Massachusetts unemployment rate for applicant's industry (from

U.S. Bureau of Labor Statistics)

Self-employed

$=\quad 1$ if self-employed

$=\mathrm{O}$ otherwise

Credit History

$=\quad 1$ if no delinquent accounts (more than 30 days past due)

$=2$ if one or two delinquent accounts

$=3$ if more than two delinquent accounts

$=4$ if insufficient credit history

$=5$ if delinquent with 60 days past due

$=6$ if serious delinquent accounts (more than 90 days late)

Mortgage History

$=\quad 1$ if no late payments

$=2$ if no payment history

$=3$ if one or two late payments

$=4$ if more than two late payments

Public Record

$=\quad \mathrm{O}$ if no public record defaults or not considered

$=1$ if any public record defaults 


\section{Table 1: Variable Definitions (cent' d.)}

Personal, Property, and Loan Characteristics

\begin{tabular}{|c|c|c|}
\hline House & & $\begin{array}{l}1 \text { if property is } 2-4 \text { family home } \\
\mathrm{O} \text { otherwise }\end{array}$ \\
\hline Special & $\begin{array}{l}= \\
=\end{array}$ & $\begin{array}{l}1 \text { if application under a special program } \\
\mathrm{O} \text { otherwise }\end{array}$ \\
\hline LTV & $=$ & ratio of loan amount and appraised value of property \\
\hline PMI Insurance & $\begin{array}{l}= \\
=\end{array}$ & $\begin{array}{l}1 \text { if PMI was denied } \\
O \text { otherwise }\end{array}$ \\
\hline Minority & $\begin{array}{l}= \\
=\end{array}$ & $\begin{array}{l}1 \text { if applicant was black or Hispanic } \\
\text { O otherwise }\end{array}$ \\
\hline Interaction Terms & & \\
\hline BlDebt & $=$ & Minority * (Debt-to-Y Ratio) \\
\hline BlCred & $=$ & Minority $*$ (Credit History) \\
\hline BlMort & $=$ & Minority $*$ (Mortgage History) \\
\hline BILTV & $=$ & Minority * (LTV) \\
\hline BlHous & $=$ & Minority * (House) \\
\hline BlWort & $=$ & Minority * (Net Worth) \\
\hline BIPMI & $=$ & Minority * (PMI Insurance) \\
\hline BlSelf & $=$ & Minority * (Self-employed) \\
\hline BlUnemp & $=$ & Minority $*(\operatorname{Pr}($ Unemp $))$ \\
\hline BlPub & $=$ & Minority * (Public Record) \\
\hline BISpec & $=$ & Minority * (Special) \\
\hline
\end{tabular}


Table 2: Sample Statistics

\begin{tabular}{|c|c|c|c|c|}
\hline & \multicolumn{2}{|c|}{ White: } & \multicolumn{2}{|c|}{ Minority: } \\
\hline & Accepted & Denied & Accepted & Denied \\
\hline $\mathbf{N}$ & 1927 & 213 & 463 & 178 \\
\hline pet. denied & 9.95 & & 27.8 & \\
\hline monthly income' & 4750 & 4248 & 4000 & 3591 \\
\hline liquid assets $(000 \mathrm{~s})^{\mathrm{a}}$ & 41 & 30 & 21 & 16.3 \\
\hline net wealth $(000 \mathrm{~s})^{\mathrm{a}}$ & 100 & 88 & 40 & 33 \\
\hline total debt/income $(\%)$ & 32.1 & 40.4 & 33.1 & 40.1 \\
\hline housing expense/income (\%) & 24.9 & 29.2 & 25.4 & 29.5 \\
\hline pet. self-employed & 11.6 & 23.0 & 8.0 & 6.7 \\
\hline LTV & .718 & .801 & .777 & .756 \\
\hline price(000s) & 199 & 189 & 151 & 145 \\
\hline pet. married & 62.9 & 51.6 & 53.8 & 53.4 \\
\hline pet. with dependents & 37.9 & 38.5 & 51.8 & 46.6 \\
\hline pet. in special programs & 11.9 & 14.1 & 41.7 & 39.9 \\
\hline pet. fixed rate loans & 67.8 & 66.7 & 58.5 & 68.0 \\
\hline pet. buying 2-4 family homes & 7.4 & 15.0 & 23.8 & 50.3 \\
\hline pet. rejected for PMI & 0.7 & 84.6 & 1.0 & 79.5 \\
\hline pet. with bad mortgage history ${ }^{\mathrm{b}}$ & 2.3 & 8.0 & 1.7 & 3.9 \\
\hline pet. with bad consumer history' & 16.7 & 39.0 & 26.8 & 56.2 \\
\hline pet. with bad public record ${ }^{\mathrm{d}}$ & 4.0 & 21.6 & 8.6 & 30.9 \\
\hline
\end{tabular}


Table 3: Correlātion Table

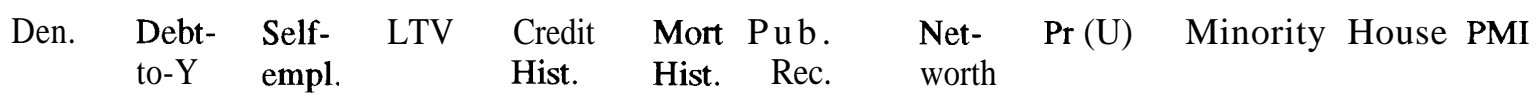

\begin{tabular}{|c|c|c|c|c|c|c|c|c|c|c|c|}
\hline Denied & $\begin{array}{l}1.00 \\
0.0\end{array}$ & & & & & & & & & & \\
\hline $\begin{array}{l}\text { Debt-to-Y } \\
\text { Ratio }\end{array}$ & $\begin{array}{l}0.24 \\
0.01\end{array}$ & $\begin{array}{l}1.00 \\
0.0\end{array}$ & & & & & & & & & \\
\hline Self-employed & $\begin{array}{l}0.05 \\
0.01\end{array}$ & $\begin{array}{l}0.04 \\
0.06\end{array}$ & $\begin{array}{l}1.00 \\
0.0\end{array}$ & & & & & & & & \\
\hline LTV & $\begin{array}{l}0.10 \\
0.01\end{array}$ & $\begin{array}{l}0.10 \\
0.01\end{array}$ & $\begin{array}{l}-0.02 \\
0.43\end{array}$ & $\begin{array}{l}0.05 \\
0.01\end{array}$ & & & & & & & \\
\hline $\begin{array}{l}\text { Credit } \\
\text { History }\end{array}$ & $\begin{array}{l}0.27 \\
0.01\end{array}$ & $\begin{array}{l}0.05 \\
0.01\end{array}$ & $\begin{array}{l}-0.02 \\
0.43\end{array}$ & $\begin{array}{l}0.05 \\
0.01\end{array}$ & $\begin{array}{l}1.00 \\
0.0\end{array}$ & & & & & & \\
\hline Mort. History & $\begin{array}{l}0.12 \\
0.01\end{array}$ & $\begin{array}{l}0.04 \\
0.03\end{array}$ & $\begin{array}{l}-0.04 \\
0.03\end{array}$ & $\begin{array}{l}0.15 \\
0.01\end{array}$ & $\begin{array}{l}0.15 \\
0.01\end{array}$ & $\begin{array}{l}1.00 \\
0.0\end{array}$ & & & & & \\
\hline Public Record & $\begin{array}{l}0.28 \\
0.01\end{array}$ & $\begin{array}{l}0.11 \\
0.01\end{array}$ & $\begin{array}{l}0.03 \\
0.09\end{array}$ & $\begin{array}{l}0.09 \\
0.01\end{array}$ & $\begin{array}{l}0.28 \\
0.01\end{array}$ & $\begin{array}{l}0.07 \\
0.01\end{array}$ & $\begin{array}{l}1.00 \\
0.0\end{array}$ & & & & \\
\hline Networth & $\begin{array}{l}-0.01 \\
0.57\end{array}$ & $\begin{array}{l}-0.10 \\
0.01\end{array}$ & $\begin{array}{l}0.12 \\
0.01\end{array}$ & $\begin{array}{l}-0.09 \\
0.01\end{array}$ & $\begin{array}{l}-0.03 \\
0.16\end{array}$ & $\begin{array}{l}-0.11 \\
0.01\end{array}$ & $\begin{array}{c}0.01 \\
0.53\end{array}$ & $\begin{array}{l}1.00 \\
0.0\end{array}$ & & & \\
\hline $\begin{array}{l}\text { Pr } \\
\text { (Unemp) }\end{array}$ & $\begin{array}{l}0.06 \\
0.01\end{array}$ & $\begin{array}{l}0.03 \\
0.14\end{array}$ & $\begin{array}{l}0.16 \\
0.01\end{array}$ & $\begin{array}{l}-0.01 \\
0.57\end{array}$ & $\begin{array}{l}-0.03 \\
0.18\end{array}$ & $\begin{array}{l}0.04 \\
0.07\end{array}$ & $\begin{array}{l}-.00 \\
0.89\end{array}$ & $\begin{array}{l}-.02 \\
0.41\end{array}$ & $\begin{array}{l}1.00 \\
0.0\end{array}$ & & \\
\hline Minority & $\begin{array}{l}0.22 \\
0.01\end{array}$ & $\begin{array}{l}0.08 \\
0.01\end{array}$ & $\begin{array}{l}-0.07 \\
0.01\end{array}$ & $\begin{array}{l}0.10 \\
0.01\end{array}$ & $\begin{array}{l}0.19 \\
0.01\end{array}$ & $\begin{array}{l}0.14 \\
0.01\end{array}$ & $\begin{array}{l}0.14 \\
0.01\end{array}$ & $\begin{array}{l}-0.08 \\
0.01\end{array}$ & $\begin{array}{l}-0.06 \\
0.01\end{array}$ & $\begin{array}{l}1.00 \\
0.0\end{array}$ & \\
\hline House & $\begin{array}{l}0.12 \\
0.01\end{array}$ & $\begin{array}{l}0.02 \\
0.29\end{array}$ & $\begin{array}{l}0.03 \\
0.18\end{array}$ & $\begin{array}{l}0.02 \\
0.31\end{array}$ & $\begin{array}{l}0.07 \\
0.01\end{array}$ & $\begin{array}{l}0.06 \\
0.01\end{array}$ & $\begin{array}{r}0.04 \\
0.07\end{array}$ & $\begin{array}{l}-0.01 \\
0.69\end{array}$ & $\begin{array}{l}0.04 \\
0.07\end{array}$ & $\begin{array}{l}0.22 \\
0.01\end{array}$ & $\begin{array}{l}1.00 \\
0.0\end{array}$ \\
\hline PMI & $\begin{array}{l}0.38 \\
0.01\end{array}$ & $\begin{array}{l}0.10 \\
0.01\end{array}$ & $\begin{array}{l}-0.02 \\
0.39\end{array}$ & $\begin{array}{l}-0.02 \\
0.40\end{array}$ & $\begin{array}{l}0.07 \\
0.01\end{array}$ & $\begin{array}{l}0.05 \\
0.01\end{array}$ & $\begin{array}{l}0.08 \\
0.01\end{array}$ & $\begin{array}{l}-0.03 \\
0.09\end{array}$ & $\begin{array}{l}0.01 \\
0.44\end{array}$ & $\begin{array}{l}0.11 \\
0.01\end{array}$ & $\begin{array}{l}0.09 \\
0.01\end{array}$ \\
\hline
\end{tabular}

NOTE: Significance levels are shown on the second line of each entry. 
Table 4: Estimates of Probability of Rejection: Munnell, et al. (1996) and Interactive Specifications

\begin{tabular}{|c|c|c|}
\hline $\begin{array}{l}\text { Specification: } \\
\text { Variable }\end{array}$ & Munnell, et al. & Interactions \\
\hline Constant & $-3.90(-14.61)^{*}$ & $-4.02(-12.72)^{*}$ \\
\hline Debt-to-Y Ratio & $.028(8.11)^{*}$ & $.022(5.76)^{*}$ \\
\hline Net worth & $.000(1.58)$ & $.000(1.68)$ \\
\hline $\begin{array}{l}\text { Credit History } \\
\text { Mortgage History } \\
\text { Public Record } \\
\text { Pr(Unemp.) } \\
\text { Self-employed }\end{array}$ & $\begin{array}{l}.142(8.24)^{*} \\
.161(2.45)^{*} \\
.731(6.80)^{*} \\
.046(2.93)^{*} \\
.263(2.56)^{*}\end{array}$ & $\begin{array}{l}.118(5.42)^{*} \\
.119(1.58) \\
.806(5.70)^{*} \\
.048(2.69)^{*} \\
.351(3.06)^{*}\end{array}$ \\
\hline $\begin{array}{l}\text { LTV } \\
\text { PMI Insurance } \\
\text { House } \\
\text { Minority }\end{array}$ & $\begin{array}{l}.616(3.22)^{*} \\
2.81(9.87)^{*} \\
.228(2.33)^{*} \\
.427(5.45)^{*}\end{array}$ & $\begin{array}{l}1.21(4.61)^{*} \\
2.89(8.05)^{*} \\
.322(2.39)^{*} \\
.242(0.36)\end{array}$ \\
\hline $\begin{array}{l}\text { BlDebt } \\
\text { BlCred } \\
\text { BIMort } \\
\text { BlLTV } \\
\text { BlHous } \\
\text { BLWort } \\
\text { BIPMI } \\
\text { BISelf } \\
\text { BIUnemp } \\
\text { BlPub }\end{array}$ & & $\begin{array}{l}.021(2.55)^{*} \\
.059(1.59) \\
.152(0.92) \\
-1.38(-3.45)^{*} \\
-.192(-0.97) \\
-.000(-0.54) \\
-.196(-0.32) \\
-.354(-1.36) \\
.000(0.00) \\
-.138(-0.63)\end{array}$ \\
\hline $\begin{array}{l}\text { LR Test of } \\
\text { Specification }\end{array}$ & & $\operatorname{Yes}\left(\chi^{2}(10)=26.9\right)$ \\
\hline
\end{tabular}




\section{Table 5: Sample Statistics of the Population Subsamples}

\begin{tabular}{|c|c|c|c|c|}
\hline & Full Sample & Minority & High Income & Low Income \\
\hline $\mathbf{N}$ & 2705 & 622 & 677 & 675 \\
\hline pet. rejected & 14.5 & 28.6 & 11.7 & 19.0 \\
\hline monthly income' & 4932 & 3991 & 9167 & 2896 \\
\hline liquid $\operatorname{assets}(000 \mathrm{~s})^{\mathrm{a}}$ & 34 & 19.2 & 83 & 20.0 \\
\hline net wealth $(000 \mathrm{~s})^{\mathrm{a}}$ & 77 & 38.0 & 254 & 38.0 \\
\hline total debt/income $(\%)$ & 33.5 & 35.1 & 30.6 & 36.3 \\
\hline housing expense/income (\%) & 25.6 & 26.7 & 21.6 & 29.2 \\
\hline pet. self-employed & 11.7 & 7.7 & 24.5 & 5.5 \\
\hline LTV & .736 & .771 & .719 & .699 \\
\hline $\operatorname{price}(000 \mathrm{~s})^{\mathrm{a}}$ & 157 & 139 & 260 & 115 \\
\hline pet. married & 60.2 & 54.0 & 75.3 & 39.4 \\
\hline pet. with dependents & 40.8 & 50.8 & 47.0 & 39.6 \\
\hline pet. in special programs & 19.0 & 41.5 & 6.2 & 43.4 \\
\hline pet. fixed rate loans & 66.5 & 61.4 & 60.1 & 68.4 \\
\hline pet. buying 2-4 family homes & 12.2 & 25.4 & 10.2 & 16.3 \\
\hline pet. rejected for PMI & 2.6 & 5.8 & 5.6 & 15.5 \\
\hline pet. with bad mortgage history ${ }^{\mathrm{b}}$ & 2.6 & 2.3 & 0.7 & 3.2 \\
\hline pet. with bad consumer history' & 26.4 & 43.2 & 24.2 & 25.8 \\
\hline pet. with bad public record ${ }^{d}$ & 7.7 & 8.7 & 6.5 & 14.8 \\
\hline pet. minority & 23.0 & & 12.1 & 38.5 \\
\hline
\end{tabular}


Table 6: Frequency and Rejection Rates of Hypothetical Types in the Data

Type
A - good credit
B - bad mortgage history
C - bad consumer credit
D - all histories bad

Frequency

355

10

738

2 $\underline{\text { Reiection Rate }}$

$3.1 \%$

$10.0 \%$

$12.0 \%$

$50.0 \%$ 
Table 7: P(Reject) of Debt-to-Income and

Loan-to-Value Ratios: Applicant Type B

\begin{tabular}{|c|c|c|c|c|}
\hline & $\begin{array}{l}\text { Minority } \\
\text { Applicant } \\
\text { P(reject) }\end{array}$ & $\begin{array}{l}\text { with White } \\
\text { Treatment } \\
\text { P(reject) }\end{array}$ & $\begin{array}{l}\text { White } \\
\text { Applicant } \\
\text { P(reject) }\end{array}$ & $\begin{array}{l}\text { with Min. } \\
\text { Treatment } \\
\text { P(reject) }\end{array}$ \\
\hline \multicolumn{5}{|l|}{ Debt-to Income } \\
\hline High Income sample means & 11.0 & 3.2 & 4.6 & 4.7 \\
\hline Full sample means & 14.4 & 4.0 & 5.3 & 7.9 \\
\hline Low Income sample means & 19.2 & 5.0 & 5.7 & 21.0 \\
\hline Minority sample means & 16.6 & 4.3 & 6.0 & 21.1 \\
\hline \multicolumn{5}{|l|}{ Loan-to-Value } \\
\hline High Income sample means & 11.2 & 42.8 & 5.1 & 0.4 \\
\hline Full sample means & 14.8 & 49.7 & 5.7 & 0.4 \\
\hline Low Income sample means & 18.4 & 53.0 & 5.5 & 0.5 \\
\hline Minority sample means & 16.5 & 52.7 & 6.3 & 0.5 \\
\hline
\end{tabular}

NOTE: Columns represent expected probabilities of rejection for hypothetical applicant B, who has a good credit history except for a poor mortgage record, at various sample population means. The first and third columns are for minority and white applicants of this type, respectively. Marginal effects are obtained in the second and fourth columns by respectively removing and applying the minority bias in the variable of interest. The top panel explores debt-to-income ratio effects while the bottom panel shows loan-to-value ratio effects. 
Figure 1: Rejection Profiles for Marginal Effect of

Debt-to-Income and Loan-to-Value by Race

(i) Debt-to-Income, Person B at Sample Means
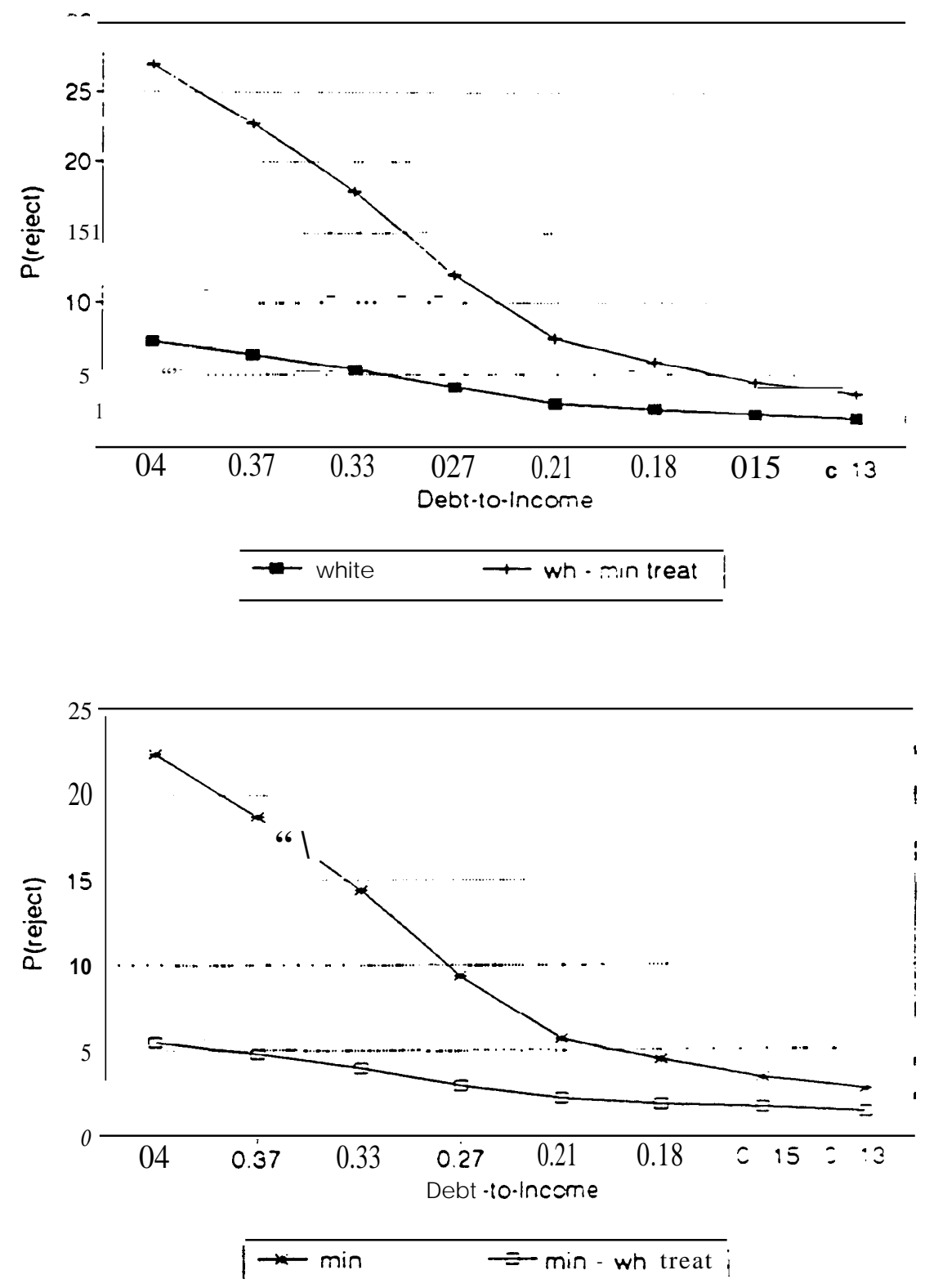

NOTE: Person B has a good credithistory except for a powr mor; ; 2 ge recors 
Figure 1: Rejection Profiles for Marginal Effect of

Debt-to-Income and Loan-to-Value by Race

(ii) Debt-to-Income, Person B at Low Income Sample Means
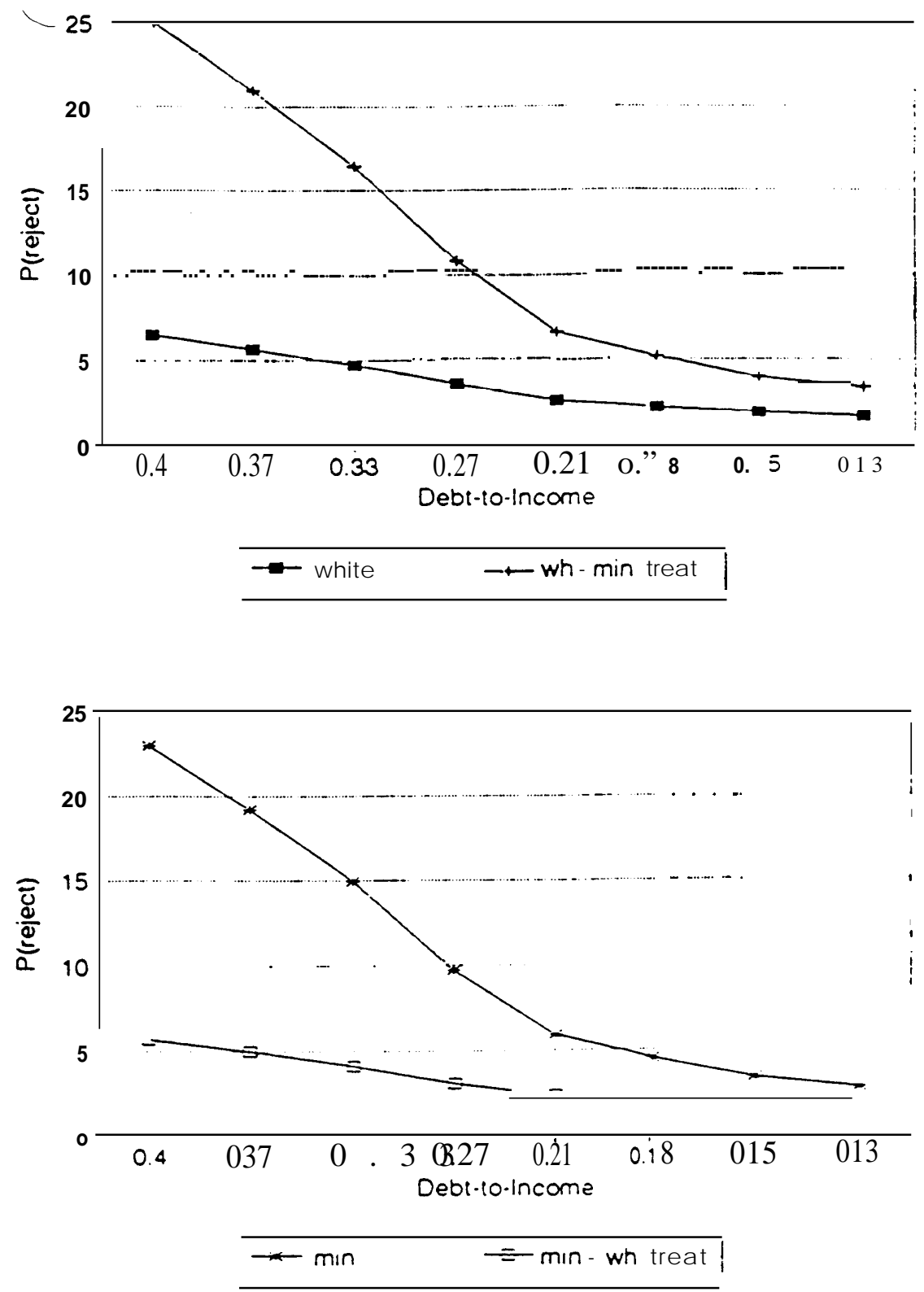

NOTE: Person B has a good credithisloryexcept for a poor mongagerecord 
Figure 1: Rejection Profiles for Marginal Effect of Debt-to-Income and Loan-to-Value by Race

(iii) Loan-to-Value, Person B at Minority Means
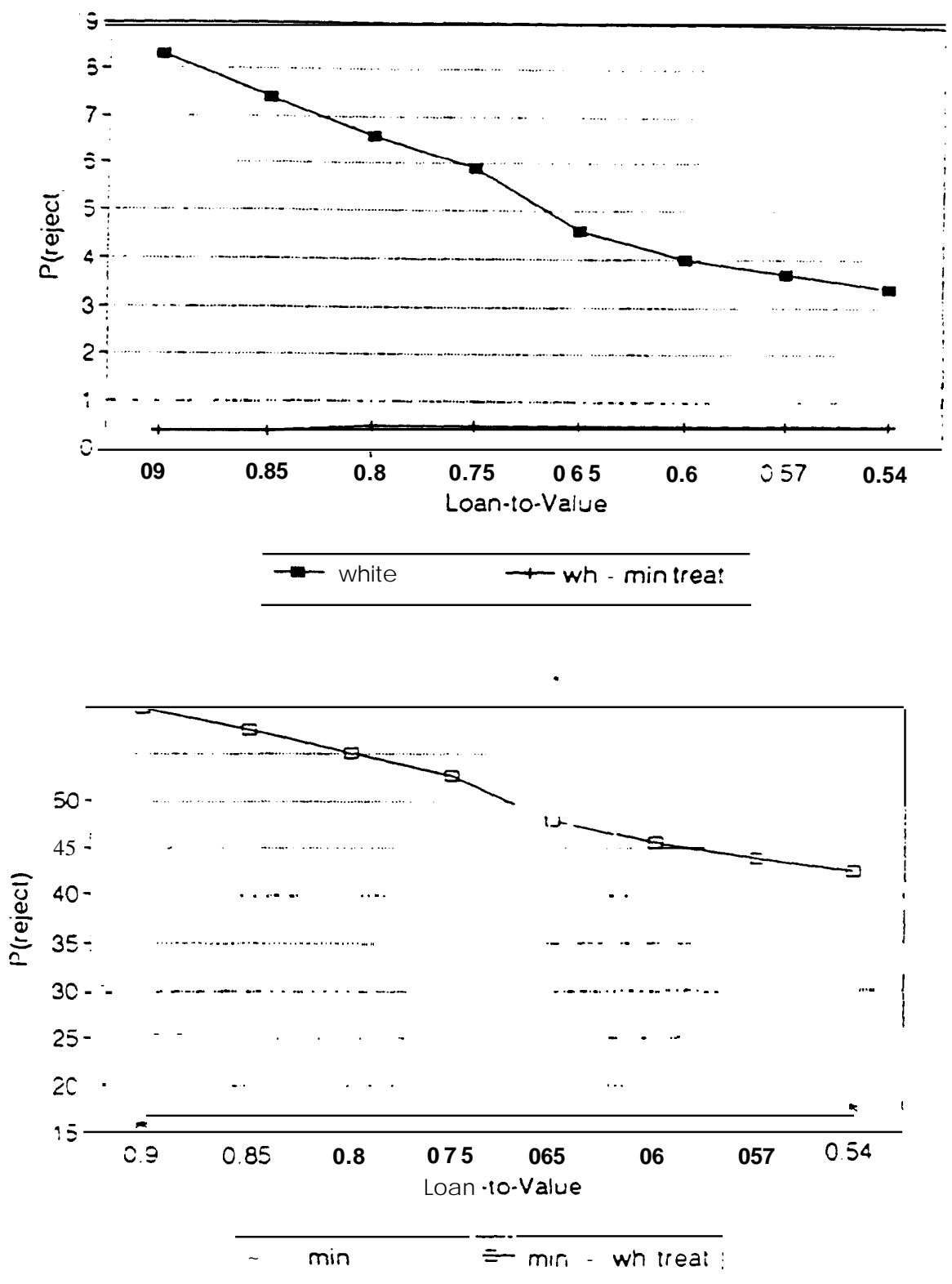

NOTE: Person B has a good credil history except for a poor mongage re:ors 
Table 8: Net Effect of Race

\begin{tabular}{|c|c|c|c|c|}
\hline & Applicant A & Applicant B & Applicant C & Applicant D \\
\hline High Income sample means & $\begin{array}{l}.012 \\
(.023)\end{array}$ & $\begin{array}{l}.066 \\
(.046)\end{array}$ & $\begin{array}{l}.051 \\
(.046)\end{array}$ & $\begin{array}{l}.162 \\
(.114)\end{array}$ \\
\hline Full sample means & $\begin{array}{l}.024 \\
(.021)\end{array}$ & $\begin{array}{l}.094 * \\
(.047)\end{array}$ & $\begin{array}{l}.077^{*} \\
(.041)\end{array}$ & $\begin{array}{l}.204 * \\
(.106)\end{array}$ \\
\hline Low Income sample means & $\begin{array}{l}.042 \\
(.024)\end{array}$ & $\begin{array}{l}.129 * \\
(.054)\end{array}$ & $\begin{array}{l}.112 * \\
(.044)\end{array}$ & $\begin{array}{l}.259^{*} \\
(.108)\end{array}$ \\
\hline Minority sample means & $\begin{array}{l}.027 \\
(.022)\end{array}$ & $\begin{array}{l}. \mathbf{1 0 3}^{*} \\
(.050)\end{array}$ & $\begin{array}{l}.086 * \\
(.041)\end{array}$ & $\begin{array}{l}.211^{*} \\
(.107)\end{array}$ \\
\hline
\end{tabular}

Numbers represent minority applicant $\mathrm{E}[\mathrm{P}($ reject)]- white applicant $\mathrm{E}[\mathrm{P}(\mathrm{reject})]$.

Standard errors are in parentheses. Significant coefficients are bold with asterisks (*).

Applicant types are: $\quad$-Person A good credit history

-Person B good history except bad mortgage record

- Person C good history except bad consumer credit record

- Person D all histories are bad 


\section{Table 9: Relative Rejection Rates where}

Significant Racial Biases are Observed

$\begin{array}{lccc} & \text { Applicant B } & \text { Applicant C } & \text { Applicant D } \\ \text { Full sample means } & 14.8 & 14.6 & 49.2 \\ & 5.4 & 6.9 & 28.8 \\ \text { Low Income sample means } & 18.4 & 18.1 & \\ & 5.5 & 6.9 & 28.9 \\ \text { Minority sample means } & & & \\ & 16.4 & 16.2 & 51.9 \\ & 6.1 & 7.7 & 30.9\end{array}$

The top number is the $\mathrm{P}($ reject) for a minority applicant with given characteristics.

The second number is the $\mathrm{P}(\mathrm{reject})$ for a white applicant with given characteristics.

Applicant types are:

-Person B

good history except bad mortgage record

-Person C

good history except bad consumer credit record

-Person D

all histories are bad 
Figure 2: Regions of Significant Racial Differences in Rejection Profiles for Marginal Effect of Debt-to-Income and Loan-to-Value

(i) Person B at Sample Means
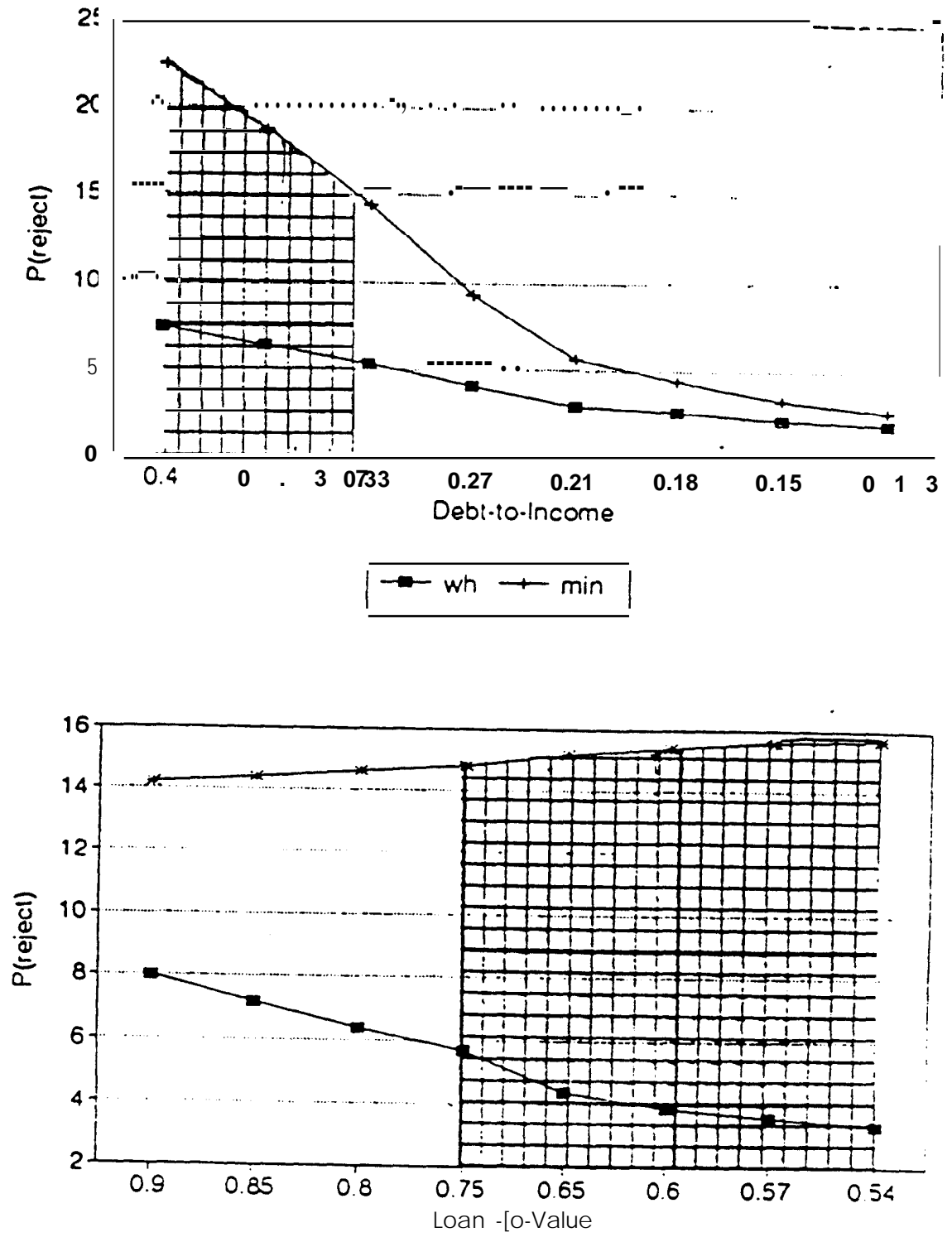

$\rightarrow$ white $\rightarrow \min$

NOTE: Pinon 4 has a gool credis hisiory escept fur a poor mongage recind 
Figure 2: Regions of Significant Racial Differences in Rejection Profiles for Marginal Effect of Debt-to-Income and Loan-to-Value

(ii) Person A at Sample Means

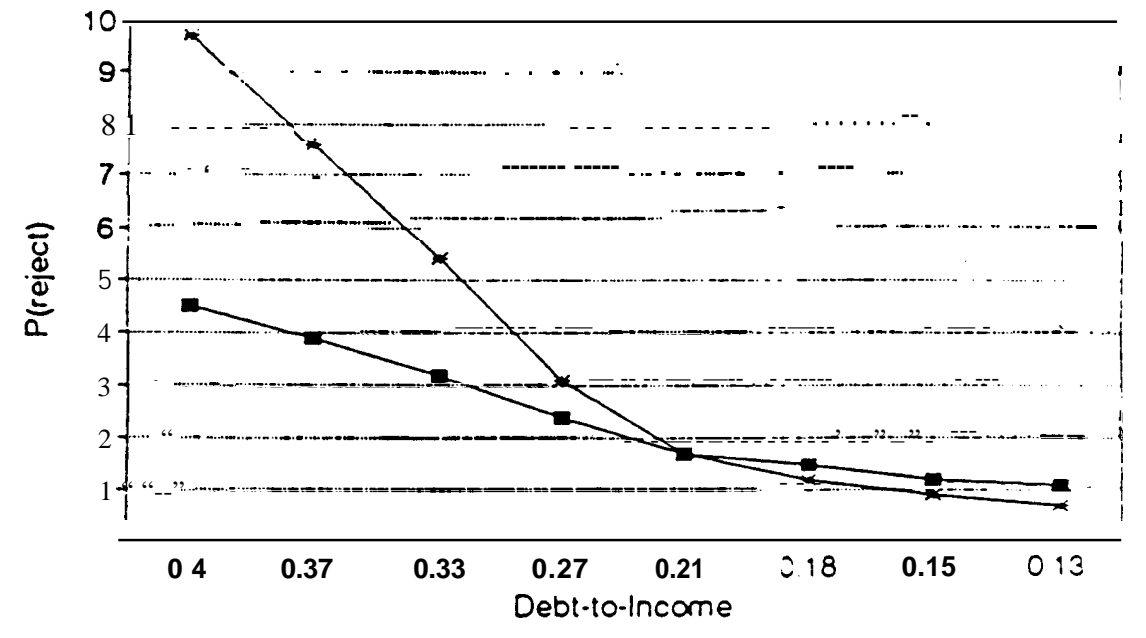

$\rightarrow$ white $\longrightarrow$ min

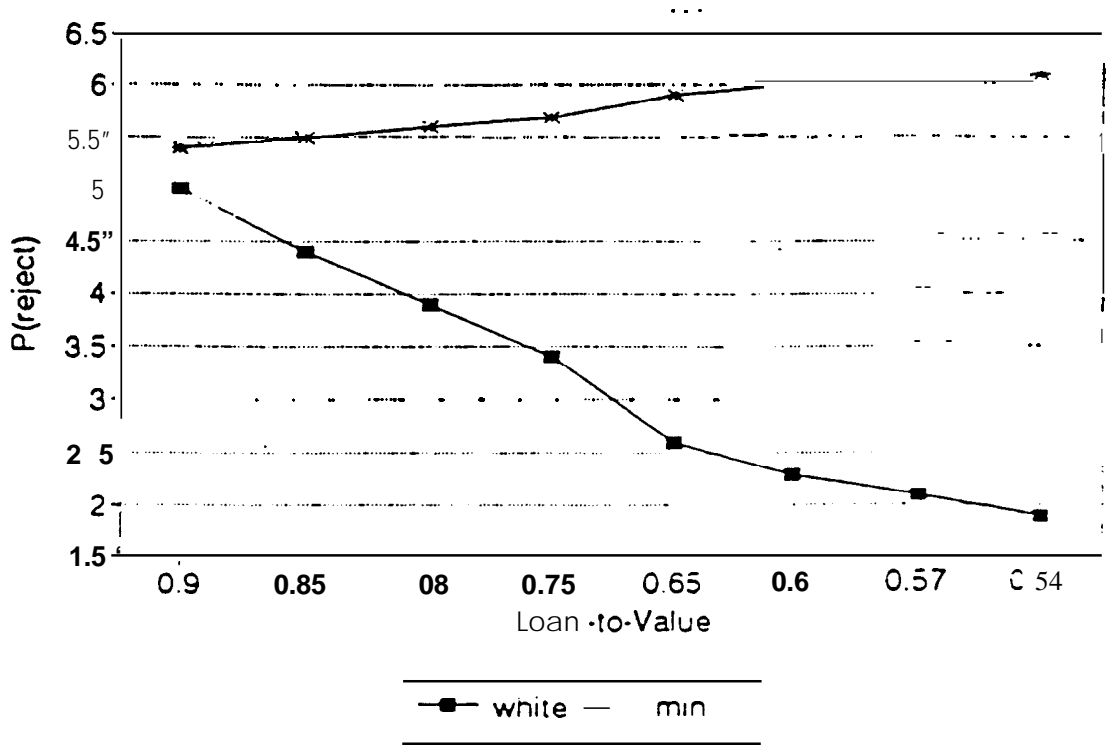

NOTE. Person A has a good credit hision: 
Figure 2: Regions of Significant Racial Differences in Rejection Profiles for Marginal Effect of Debt-to-Income and Loan-to-Value

\section{(iii) Person B at High Income Means}
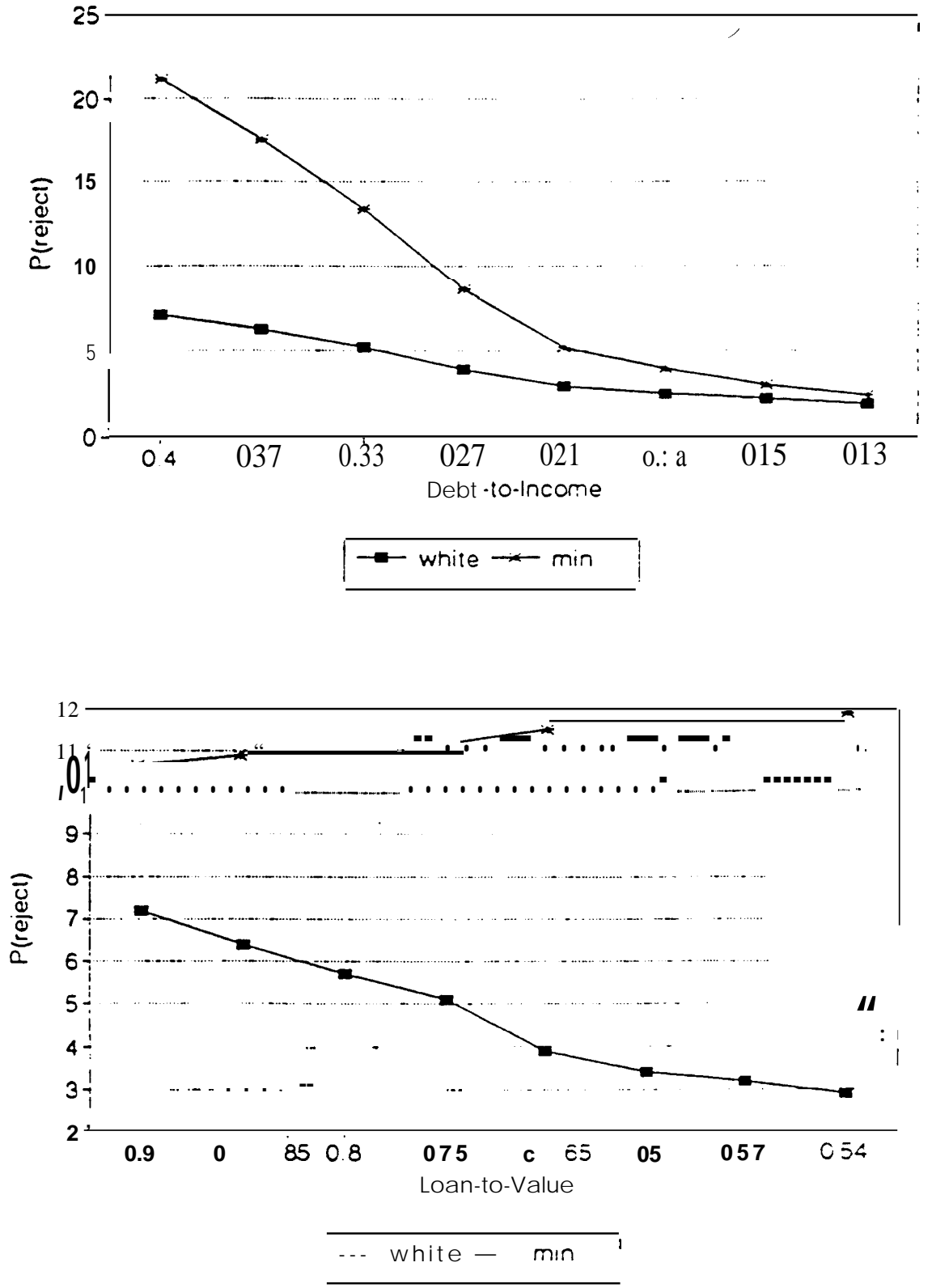

NOTE: Person'B has a good credit history except for a poor mungage recort 


\begin{abstract}
APPENDIX
The tables in this Appendix explore alternate samples and specifications of the main specification in Table 4. Table Al shows estimates of the probability of rejection using the full Federal Reserve Bank of Boston sample, which was found to have errors. These estimates do not match those using a cleansed dataset, particularly when the interactive specification is considered. The coefficient on credit history is negative, which is quite surprising, and the interactive LTV term is no longer statistically significant. Using the full sample, the only variable which demonstrates a racial differential is the debt-to-income ratio. These differences raise questions about the feasibility of using the full sample for conducting analyses.

A shorter specification including only those interactive terms found to be significant is estimated in Table A2. As can be seen, no substantial differences from the richer specification emerge. Likelihood ratio tests indicate that this specification is significantly different from the original Munnell, et al. specification and from specifications including only one of the two interactive terms. However, the specification does not differ substantially in explanatory power from the longer design used in the text.

Table A3 shows estimates that include an additional variable, a dummy variable indicating whether the application was for a special mortgage program. As is clear, this variable is not statistically significant and does not alter the results qualitatively.

Table A4 estimates the relation of Table 4 using a logit function rather than a probit. The magnitude of the coefficients from these estimates differ from the probit estimates, as might be expected, but the overall relations are identical to those from before.
\end{abstract}


Table Al: Estimates of Probability of Rejection using Full Sample: Munnell, et al. (1992) and Interactive Specifications

\begin{tabular}{|c|c|c|}
\hline $\begin{array}{l}\text { Specification: } \\
\text { Variable }\end{array}$ & Original & With Interactions \\
\hline Constant & $-3.73(-15.9)^{*}$ & $-3.49(-13.6)^{*}$ \\
\hline Debt-to-Y Ratio & $.029(8.59) *$ & $.023(6.30)^{*}$ \\
\hline Net worth & $.000(1.40)$ & $.000(.1 .41)$ \\
\hline Credit History & $.150(8.97)^{*}$ & $-.131(-6.25)^{*}$ \\
\hline Mortgage History & $.178(2.80)^{*}$ & $.152(2.13)^{*}$ \\
\hline Public Record & $.719(6.89)^{*}$ & $.807(5.95)^{*}$ \\
\hline $\operatorname{Pr}$ (Unemp.) & $.044(2.85)^{*}$ & $.044(2.60)^{*}$ \\
\hline Self-employed & $.252(2.53) *$ & $.318(2.87)^{*}$ \\
\hline LTV & $.296(3.11)^{*}$ & $.329(3.32)^{*}$ \\
\hline PMI Insurance & $2.83(9.97)^{*}$ & $2.93(8.26)^{*}$ \\
\hline House & $.272(2.98)^{*}$ & $.347(2.77)^{*}$ \\
\hline Minority & $.418(5.49)^{*}$ & $-.569(-.899)$ \\
\hline BIDebt & & $.021(2.60)^{*}$ \\
\hline BlCred & & $.052(1.46)$ \\
\hline BIMort & & $.148(.914)$ \\
\hline BILTV & & $-.308(-1.03)$ \\
\hline BlHous & & $-.142(-.773)$ \\
\hline BLWort & & $-.000(-.629)$ \\
\hline BIPMI & & $-.267(-.446)$ \\
\hline BISelf & & $-.277(-1.10)$ \\
\hline BlUnemp & & $.001(.015)$ \\
\hline BlPub & & $-.196(-.913)$ \\
\hline $\begin{array}{l}\text { LR Test of } \\
\text { Specification }\end{array}$ & & No $\left(\chi^{2}(10)=15.35\right)$ \\
\hline
\end{tabular}

NOTE: t-statistics in parentheses. Significant coefficients are bold with asterisks $(*)$. 
Table A2: Estimates of Probability of Rejection: Munnell, et al. (1992) and Shorter Interactive Specifications

Specification:

Variable

Constant

Debt-to-Y Ratio

Net worth

Credit History

Mortgage History

Public Record

$\operatorname{Pr}$ (Unemp.)

Self-employed

LTV

PMI Insurance

House

Minority

BIDebt

BILTV

LR Test of

Specification

relative to:

Munnell, et al.

bldebt only specification

blltv only specification

all interactions specification
Munnell, et al.

$-3.90(-14.61)^{*}$

$.028(8.11)^{*}$

$.000(1.58)$

$.142(8.24)^{*}$

$.161(2.45)^{*}$

$.731(6.80)^{*}$

$.046(2.93) *$

$.263(2.56)^{*}$

$.616(3.22)^{*}$

$2.81(9.87)^{*}$

$.228(2.33) *$

$.427(5.45)^{*}$

Interactions

$-4.12(-13.57)^{*}$

$.022(5.86) *$

$.000(1.72)$

$.139(8.01)^{*}$

$.149(2.25)^{*}$

$.746(6.89)^{*}$

$.047(2.93)^{*}$

$.275(2.67)^{*}$

$1.19(4.56)^{*}$

$2.81(9.76)^{*}$

$.223(2.26)^{*}$

.715 (1.68)

.022 (2.66)

$-1.36(-3.44)^{*}$

NOTE: t-statistics in parentheses. Significant coefficients are bold with asterisks $\left(^{*}\right)$. 
Table A3: Estimates of Probability of Rejection: Munnell, et al. (1996) and Interactive Specifications, including dummy for Special Programs

\begin{tabular}{|c|c|}
\hline $\begin{array}{l}\text { Specification: } \\
\text { Variable }\end{array}$ & Munnell, et al. \\
\hline Constant & $-3.88(-14.53) *$ \\
\hline Debt-to-Y Ratio & $.028(8.11)^{*}$ \\
\hline Net worth & $.000(1.53)$ \\
\hline Credit History & $.142(8.23)^{*}$ \\
\hline Mortgage History & $.166(2.52)^{*}$ \\
\hline Public Record & $.729(6.77)^{*}$ \\
\hline $\operatorname{Pr}$ (Unemp.) & $.046(2.87)^{*}$ \\
\hline Self-employed & $.257(2.51)^{*}$ \\
\hline LTV & $.598(3.10)^{*}$ \\
\hline PMI Insurance & $2.82(9.90)^{*}$ \\
\hline House & $.231(2.35)^{*}$ \\
\hline Special & $-.081(-0.88)$ \\
\hline Minority & $.447(5.48)^{*}$ \\
\hline \multicolumn{2}{|l|}{ BlDebt } \\
\hline \multicolumn{2}{|l|}{ BlCred } \\
\hline \multicolumn{2}{|l|}{ BlMort } \\
\hline \multicolumn{2}{|l|}{ BILTV } \\
\hline \multicolumn{2}{|l|}{ BlHous } \\
\hline \multicolumn{2}{|l|}{ BLWort } \\
\hline \multicolumn{2}{|l|}{ BIPMI } \\
\hline \multicolumn{2}{|l|}{ BlSelf } \\
\hline \multicolumn{2}{|l|}{ BlUnemp } \\
\hline \multicolumn{2}{|l|}{ BlPub } \\
\hline \multicolumn{2}{|l|}{ BlSpec } \\
\hline LR Test of & \\
\hline Specification & \\
\hline
\end{tabular}

Interactions

$-4.02(-12.72)^{*}$

$.022(5.76) *$

$.000(1.66)$

$.118(5.41)^{*}$

$.121(1.60)$

$.807(5.71)^{*}$

$.047(2.68) *$

$.350(3.05) *$

$1.21(4.61)^{*}$

$2.90(8.06)^{*}$

$.326(2.41)^{*}$

$-.046(-0.35)$

$.450(0.66)$

$.020(2.45)^{*}$

$.059(1.59)$

$.186(1.12)$

$-1.55(-3.78)^{*}$

$-.204(-1.03)$

$-.000(-0.91)$

$-.094(-0.15)$

$-.385(-1.49)$

$.007(0.17)$

$-.153(-0.69)$

-.231 (-1.21)

NOTE: t-statistics in parentheses. Significant coefficients are bold with asterisks (*). 
Table A4: Logit Estimates of Probability of Rejection: Munnell, et al. (1992) and Interactive Specifications

Specification:

Variable

Constant

Debt-to-Y Ratio

Net worth

Credit History

Mortgage History

Public Record

$\operatorname{Pr}$ (Unemp.)

Self-employed

LTV

PMI Insurance

House

Minority

BIDebt

BlCred

BIMort

BILTV

BlHous

BlWort

BIPMI

BISelf

BIUnemp

BIPub

LR Test of

Specification
Munnell, et al.

$-7.46(-13.81)^{*}$

$.056(7.82)^{*}$

$.000(1.60)$

$.270(8.58)^{*}$

$.327(2.66) *$

$1.25(6.82)^{*}$

$.088(2.93)^{*}$

$.496(2.58) *$

$1.25(3.32)^{*}$

$5.08(8.33)^{*}$

$.423(2.36)^{*}$

.796 $(5.53)^{*}$

Interactions

$-7.79(-11.82)^{*}$

$.045(5.37)^{*}$

$.000(1.63)$

$.237(5.82)^{*}$

$.244(1.68)$

$1.43(5.90)^{*}$

$.088(2.61)^{*}$

$.669(3.05)^{*}$

2.51(4.76)*

$5.22(6.93) *$

$.623(2.49)^{*}$

$1.05(.829)$

$.036(2.18)^{*}$

$.066(1.01)$

$.233(.794)$

$-2.79(-3.67) *$

$-.371(-1.04)$

$-.000(-.508)$

$-.399(-.309)$

-.688(-1.44)

$-.006(-.076)$

$-.286(-.759)$

Yes $\left(\chi^{2}(10)=25.30\right)$

NOTE: t-statistics in parentheses. Significant coefficients are bold with asterisks(*). 